\title{
A ESCREVIVÊNCIA DE CONCEIÇÃO EVARISTO COMO RECONSTRUÇÃO DO TECI- DO DA MEMÓRIA BRASILEIRA
}

(The writinscreening of Evaristo Conception as a reconstruction of the brazilian tissue of memory)

(La escribivencia de Conceição Evaristo como reconstrucción de la urdidura de la memoria brasileña)

\author{
Maria de Lourdes Rossi Remenche ${ }^{1}$ \\ Universidade Tecnológica Federal do Paraná \\ Juliano Sippel ${ }^{2}$ \\ Universidade Tecnológica Federal do Paraná
}

\section{RESUMO}

Neste artigo apresentamos um estudo da poesia de Conceição Evaristo como acontecimento que perturba a regularidade da memória social da população negra no Brasil. A partir de uma abordagem interpretativista e com base nos estudos da análise do discurso de tradição francesa, tomamos a materialidade dos versos da escritora em suas dimensões horizontais e verticais para analisar os efeitos de sentido produzidos a cada vez que tais enunciados surgem como um acontecimento, provocando fissuras nas redes que constituem o tecido da memória nacional. A análise revela que a escrita da autora se constitui em um acontecimento discursivo profundamente atravessado por um sujeito cujos pés estão fincados na história.

Palavras-chave: Formações discursivas. Memória discursiva. Acontecimento discursivo. Tecido da memória.

\begin{abstract}
In this article we presented a study about Conceição Evaristo's poetry as an event which disturbs the regularity of the social memory of black communities in Brazil. Based on both interpretative approach and French Discourse Analysis studies, we took into account the materiality of the writer's verses. In this sense, we analysed their horizontal and vertical dimensions. Thereby, we were able to study the meaning effects produced each time these verses were enunciated, in this regard, by appearing as an event, they have caused fissures in the network in which the national tissue of memory is constituted. Our analysis reveals that, the author's writing is a discursive event which is profoundly crossed by a subject whose feet are firmly planted in the history.
\end{abstract}

Keywords: Discursive formations. Discursive memories. Discursive event. Tissue of memory.

\section{RESUMEN}

En este artículo presentamos un estudio de la poesía de Conceição Evaristo como un acontecimiento que perturba la regularidad de la memoria social de la población negra en Brasil. Con un abordaje interpretativo y basado en los estudios del análisis del discurso de tradición francesa, tomamos la materialidad de los

\footnotetext{
1 Maria de Lourdes Rossi Remenche é doutora em Linguística pela Faculdade de Filosofia e Letras da Universidade de São Paulo; mestre em Estudos da linguagem pela Universidade Estadual de Londrina (UEL); Graduada em Letras Vernáculas e Anglo pela Universidade de Londrina (UEL). Atua como professora adjunta III da Universidade Tecnológica Federal do Paraná (UTFPR), é docente do Programa de Pós-graduação em Estudos de Linguagens/PPGEL, e líder do Grupo de Pesquisa em Linguística Aplicada (GRUPLA). mremenche@utfpr.edu.br

2 Juliano Sippel é mestre em Estudos de linguagens pela Universidade Tecnológica Federal do Paraná (UTFPR); especialista em Alfabetização e letramento pela Universidade Positivo; especialista em Compreensão de textos e tradução da língua espanhola pela Faculdade de Educação São Luís; graduado em Letras Português-Espanhol pela Universidade Federal do Paraná (UFPR). Atua como editor multimídia, na escrita e edição de recursos educacionais digitais para a Educação Básica. sippeljuliano@gmail.com
} 
versos de la poeta en sus dimensiones horizontales y verticales para analizar los efectos de sentido que se producen cada vez que dichos enunciados figuran como un acontecimiento que causa fisuras en las redes que constituyen la urdidura de la memoria nacional. El análisis muestra que la escritura de la autora está anclada en un acontecimiento discursivo profundamente atravesado por un sujeto que tiene los pies clavados en la historia.

Palabras-clave: Formaciones discursivas. Memoria discursiva. Acontecimiento discursivo. Urdidura de la memoria.

Recebido em: março 2019

Aceito em: julho 2019

DOI: $\underline{10.26512 / \text { les.v20i2.23381 }}$

\section{Tecendo as Primeiras Ideias}

Os exercícios de memória constituem nossas vivências e materializam nossas lembranças pessoais e coletivas. Realizar esses exercícios de retomada contribui para que possamos entender a nós mesmos e aos diferentes contextos em que estamos inseridos. Nessa perspectiva, conceber a materialidade da linguagem como tecido da memória é considerá-la instável, móvel, reorganizável e que pode, portanto, esgarçar-se e remodelar-se a cada acontecimento, que perfura e desloca esse tecido, obrigando-o a nos entrelaçar em novos espaços (COURTINE, 2006). Desse entrelaçamento surgem novos dizeres, que produzem efeitos de sentido, percorrem/permeiam diferentes formações discursivas e interpelam novas posições-sujeito.

Considerando essas ideias, neste artigo analisaremos três poemas de Conceição Evaristo como acontecimento que perturba a regularidade da memória social da população negra no Brasil. Para tanto, iniciamos com uma breve retomada de algumas ideias e categorias presentes na teoria de discurso pecheutiana, que tomamos de base para a análise proposta.

Para discutir a categoria de sujeito, Pêcheux (2014) se volta às reflexões do filósofo Louis Althusser, em especial à sua noção de ideologia ${ }^{3}$, ancorada no conceito de reprodução/transformação das condições de produção. O trabalho de Althusser demonstra que são as condições econômicas o fator condicionante de tal relação, de forma que falar de reprodução/transformação é falar em produção baseada em divisão de classes - sobretudo em luta de classes, que atravessa todos os lados das situações de produção ${ }^{4}$. Pêcheux introduz na sequência outro conceito desenvolvido por Althusser e que perpassa toda a construção de sua teoria materialista do

\footnotetext{
${ }^{3}$ Althusser (1980, p. 69) vale-se da reelaboração do conceito de idelogia forjado por Destutt de Tracy e proposto por Marx, segundo o qual "A ideologia passa então a ser o sistema das ideias, das representações, que domina o espírito de um homem ou de um grupo social".

${ }^{4}$ Ao dizer situações de produção, Althusser referia-se às situações de produção de artefatos, de produtos fabricados pela força do trabalho humano. Quando trazemos esse conceito para a construção de uma teoria materialista de discurso, devemos ter em conta que Pêcheux amplia a noção de situação de produção, utilizando-a para designar também a produção de discursos - que, neste trabalho, são os poemas da Conceição Evaristo.
} 
discurso, a noção de aparelhos ideológicos de Estado ${ }^{5}$, fundada na ideia de que a ideologia atravessa a luta de classes e é propagada por esses aparelhos ideológicos - os espaços de propagação das ideologias como a igreja, a escola, os meios de comunicação, a família, entre outros.

Outro aspecto relevante das ideologias, conforme Pêcheux, é que são constituídas de práticas e não são impostas de forma igual à sociedade - o que acentua o caráter de luta de classe por ser "impossível atribuir a cada classe sua ideologia" (2014, p. 130). A ideologia da classe dominante torna-se predominante por meio da atuação dos aparelhos ideológicos de Estado (local de propagação das ideologias e das condições da reprodução/transformação de relações de produção).

Ao dar eco ao entendimento de ideologia e as formas de propagação de Althusser, Pêcheux (2014) introduz a noção de sujeito como evidência natural da produção/reprodução da força de trabalho dissimulada no interior do aparelho ideológico. Os aparelhos ideológicos de Estado ocultam em seu interior a luta de classes, propagando ideologias de forma que, para Pêcheux, "a ideologia interpela os indivíduos em sujeitos" (p. 134). Podemos pensar que o sujeito é capturado pela ideologia em um movimento inconsciente, mas que faz parte de suas ações, de suas situações de produção. Entretanto, Pêcheux (2014) afirma que antes dessa interpelação o indivíduo já é sujeito e evoca, para construir uma imagem para essa formulação teórica, a figura do barão de Münchausen, que se alçou de um pântano, puxando-se pelo próprio cabelo. Por meio dessa imagem, Pêcheux articula a interpelação ao que denomina efeito Münchausen, isto é, um efeito circular que representa o sujeito constituído, sendo interpelado pelas ideologias e reproduzindo-as em movimento constante e de retroalimentação.

Com base nesse processo, Pêcheux (2014) propõe que o sentido não existe em si mesmo, e descarta qualquer possibilidade de sentido atrelado, isto é, fixado a determinadas unidades linguísticas. Para o filósofo, o sentido é determinado e resultado das posições ideológicas que estão em jogo no momento da enunciação, fazendo com que as palavras signifiquem dentro da formação ideológica de quem as enuncia ${ }^{6}$. O sentido, portanto

\footnotetext{
${ }^{5}$ Segundo Althusser (1980, p. 43) "Designamos por Aparelhos Ideológicos de Estado um certo número de realidades que se apresentam ao observador imediato sob a forma de instituições distintas e especializadas. Propomos uma lista empírica destas realidades que, é claro, necessitará de ser examinada pormenorizadamente, posta à prova, retificada e reelaborada". O filósofo opõe, dessa forma, esses aparelhos aos denominados aparelhos repressores de Estado, isto é, aparelhos que, na tradição marxista de Estado, são responsáveis pelo exercício de poder e controle com base na repressão - as práticas jurídicas, as prisões, a polícia, por exemplos. O poder exercido pelos aparelhos ideológicos, pois, não tem como base a repressão, mas se exerce pela propagação de ideologias.

${ }^{6}$ Podemos pensar em um exemplo que evidencia a diferença do signo conforme as condições de quem o produz/reproduz na língua: terra tem para um geógrafo, por exemplo, um sentido bastante diferente que para um membro do MST, reforçando que "todo processo discursivo se inscreve numa relação ideológica de classes" (PÊCHEUX, 2014, p. 82).
} 
existe exclusivamente nas relações de metáfora (realizadas em efeitos de substituição, paráfrases, formações de sinônimos), das quais certa formação discursiva vem a ser historicamente o lugar mais ou menos provisório: as palavras, expressões e proposições recebem seus sentidos da formação discursiva à qual pertencem. (PÊCHEUX, 2014, p. 240)

Nesse excerto, Pêcheux mobiliza o conceito de formação discursiva, elaborado por Foucault em 1969. Isso ocorre porque Pêcheux, em sua elaboração teórica, dá-se conta que apenas o enunciado isolado não era suficiente para explicar as inquietações daquele período a respeito das relações de poder e legitimação de saberes presentes na sociedade. Já Foucault, em sua reflexão teórica, volta-se para conjuntos de enunciados com vistas a analisar a construção de unidades invisíveis que possibilitariam explicar determinados fenômenos. Para o filósofo,

No caso em que se puder descrever, entre um certo número de enunciados, semelhante sistema de dispersão, e no caso em que entre os objetos, os tipos de enunciação, os conceitos, as escolhas temáticas, se puder definir uma regularidade (uma ordem, correlações, posições e funcionamentos, transformações), diremos, por convenção, que se trata de uma formação discursiva. (FOUCAULT, 2008, p. 43)

Temos aí a gênese do conceito de formação discursiva - conceito que atravessa toda a construção da teoria materialista de Pêcheux, que se ancora em Althusser e sua noção de ideologia e o reelabora. Pêcheux (2014) agrega força à ideologia à ideia de sua propagação por meio dos aparelhos ideológicos de Estado, e argumenta que uma formação ideológica define o que pode e deve ser dito em determinada conjuntura: "aquilo que, numa formação ideológica dada, isto é, a partir de uma posição dada numa conjuntura dada, determinada pelo estado de luta de classes, determina o que pode e deve ser dito" (p. 147). Há uma formação discursiva oculta (composta por elementos que estão fora da enunciação), articulada por meio dos discursos e, para alcançá-la, se faz necessário observar a posição dos sujeitos para compreender essa possibilidade de dizer em determinada conjuntura. Compreendemos, pois, que a posição-sujeito se dá pela interpelação da ideologia, presente no interior das formações discursivas, alicerçada pelos aparelhos ideológicos de Estado.

Pêcheux (2014) argumenta, além disso, que há sempre interdiscursos no interior das formações discursivas “no fato de que 'algo fala' (ça parle) sempre 'antes, em outro lugar e independentemente"” (p. 151). Há sempre um já-dito sobre aquilo que se diz e os sujeitos, interpelados pelas ideologias dissimuladas no interior das formações discursivas, reproduzem os interdiscursos "enquanto sistema de evidências e de significações percebidas - aceitas experimentadas" (p. 151), como retomadas dos já-ditos. 
Nessa perspectiva, os interdiscursos são princípio integrador do funcionamento da discursividade "porque os elementos de uma sequência textual, funcionando em uma formação discursiva dada, podem ser importados [...] de uma sequência pertencente a uma outra formação discursiva que as referências discursivas podem se construir e se deslocar historicamente" (PÊCHEUX, 2015a, p. 158). Os intradiscursos, por sua vez, são o fio condutor dos discursos, isto é, os espaços em que se elencam os sintagmas dos enunciados. Assim, as referências discursivas dos objetos a que nos referimos assumem uma dimensão vertical e outra horizontal ${ }^{7}$. As formações discursivas combinam diferentes efeitos de interdiscursos, isto é, referências discursivas e históricas que se constroem e de igual maneira se deslocam verticalmente no interior de formações discursivas, via interdiscursos, organizando-se horizontalmente, via intradiscursos.

Outra categoria proposta por Pêcheux (1999), e que será alicerce para a nossa análise, é a de memória discursiva. O filósofo reconhece a memória não como algo que deve ser entendido na individualidade, mas como uma prática inserida na sociedade. Pêcheux aponta que o estudo desse campo do conhecimento se insere na linguística e nas disciplinas de interpretação - como os estudos sobre discurso e semiótica - e reconhece que, embora a imagem atue como um operador da memória social (por meio de sua repetição e posterior reconhecimento), há, antes, um percurso discursivo entrecruzado no "choque de um acontecimento histórico singular e o dispositivo complexo de uma memória" (1999, p. 51), que aponta para uma passagem do visível ao nomeado.

Nesse sentido, a memória aparece como "estruturação de materialidade discursiva complexa, estendida em uma dialética da repetição e da regularização" (PÊCHEUX, 1999, p. 52). A memória discursiva passa a ser aquilo que, diante de um texto que surge como determinado acontecimento, reestabelece os implícitos, os elementos relatados anteriormente ao surgimento do acontecimento. Pêcheux problematiza o lugar de tais elementos implícitos e sua disposição na memória discursiva e, ao fazer isso, compartilha da hipótese de $\operatorname{Achard}^{8}$ (1999), segundo a qual não encontramos esses elementos de forma estável e sedimentada. Por meio da repetição, ocorre a “formação de um efeito de série, pelo qual uma 'regularização' [...] se iniciaria, e seria nessa própria regularização que residiriam os implícitos, sob a forma de remissões, de retomadas e efeitos de paráfrase" (1999, p. 52); isto é, a repetição seria a responsável por uma estabilização da memória

\footnotetext{
${ }^{7}$ Indurski (2003) sistematiza essa formulação teórica, ao afirmar que o sujeito, ao enunciar, reproduz discursos outros (os já-ditos) "os quais são retomados de sua dimensão vertical, de-sintagmatizada, deslinearizada e inscritos no discurso do sujeito que, ao deles se apropriar, dá-lhes uma dimensão horizontal, sintagmatizada, ou seja, o sujeito lineariza esses saberes, os enunciados, em seu discurso, dando-lhes uma formulação própria...” (p. 102).

${ }^{8}$ Achard (1999) afirma que a memória é acionada como forma de enquadrar o implícito e controlar seus efeitos de paráfrases. Segundo o autor "o implícito trabalha então sobre a base de um imaginário que o representa como memorizado, enquanto cada discurso, ao pressupô-lo, vai fazer apelo a sua (re)construção, sob a restrição 'no vazio' de que eles respeitem as formas que permitam sua inserção por paráfrase” (p. 13).
} 
social. Há que se considerar, contudo, que o surgimento de um novo acontecimento pode desestabilizar o que antes havia sido regularizado pela repetição, abalando a memória e deslocando os implícitos associados à anterior regularização.

Pêcheux argumenta que há sempre um jogo de forças na memória quando esse novo acontecimento surge e desestabiliza o que denomina rede dos implícitos. Nessa perspectiva, verificamos que acontecimento e memória se situam em planos distintos: o primeiro provoca e introduz uma mudança nos discursos; a segunda, representa a possibilidade de estabilização do discurso. A memória, pois, diz Pêcheux, "não pode ser concebida como uma esfera plana, cujas bordas seriam transcendentais históricos e cujo conjunto seria um sentido homogêneo" (1999, p. 56), mas como um espaço móvel, de descolamentos, conflitos e posteriores retomadas. A repetição de enunciados atua como motor de funcionamento da memória, formando regularidades discursivas e estabilizando o discurso. Tal estabilização, entretanto, não garante a sua regularidade, pois pode ser rompida a cada novo acontecimento discurso, transformando a memória em "espaço de desdobramentos, réplicas, polêmicas e contradiscursos" (1999, p. 56).

$\mathrm{O}$ acontecimento discursivo se situa "no ponto de encontro de uma atualidade e uma memória" (PÊCHEUX, 2015b, p. 16). Devemos resgatar nesse momento as noções de dimensão vertical e horizontal dos enunciados, visto que, é no primeiro eixo que se situam os interdiscursos, as formações discursivas e a memória discursiva; no eixo horizontal, se situa a estrutura do enunciado - sua formulação enunciada pelos sujeitos. Temos, dessa forma, que o acontecimento discursivo se encontra no cruzamento de interdiscurso com intradiscurso: "este ponto de encontro é onde o enunciado, proveniente na estrutura interdiscursiva, pelo viés da repetição, é inscrito na estrutura do discurso do sujeito, no intradiscurso" (INDURSKI, 2003, p. 103).

Vimos que um enunciado remete sempre a uma existência anterior (a uma rede de trajetos inscritos em formações discursivas e memória que o sustenta) em posição vertical e à sua própria formulação na posição horizontal. A repetibilidade de um enunciado mobiliza os dois eixos, de forma que um discurso se formula no seu entrecruzamento e, nesse momento, se instauram os efeitos de memória. Os discursos transitam entre estrutura e acontecimento de forma a se tornar difícil identificar em que local ocorrem os deslizamentos que transformam os efeitos de sentido alcançados a cada nova enunciação. Assim, por existir,

todo discurso marca a possibilidade de uma desestruturação-reestruturação dessas redes e trajetos: todo discurso é o índice potencial de uma agitação nas filiações sócio-históricas de identificação na medida em que ele constitui ao mesmo tempo um efeito dessas filiações e um trabalho [...] de deslocamento no seu espaço... (PÊCHEUX, 2015b, p. 56) 
O acontecimento marca uma possibilidade de desestabilizar e reestruturar redes e trajetos sociais da memória e de diferentes formações discursivas. Nesse sentido, retomamos Pêcheux (1999) ao afirmar que a regularidade da memória discursiva pode ser abalada a cada novo acontecimento discursivo que perfura a memória, causando-lhe fissuras em sua estrutura vertical, possibilitando novos dizeres, novos efeitos de sentido que repercutem na estrutura horizontal. A cada acontecimento, a memória social é desestabilizada e os discursos se propagam por novos caminhos, reorganizando e ressignificando o que Courtine (2006) denomina tecido da memória.

$\mathrm{Na}$ sequência, analisaremos três poemas nos quais a posição-sujeito ocupada por Conceição Evaristo produz acontecimentos que perturbam a regularidade e repetibilidade dos enunciados sobre a condição do negro brasileiro em suas duas dimensões - nas formações discursivas em que se inscrevem os dizeres sobre a população negra, e nos próprios enunciados que são produzidos nos discursos dos sujeitos. Perfurada a cada acontecimento, a memória social percorre novos trajetos e sustenta novos efeitos de sentido, os quais reorganizam seu tecido, possibilitando novas formações discursivas e efeitos de paráfrase. Antes, contudo, faremos uma breve contextualização do percurso trilhado por Evaristo em sua formação como intelectual da literatura brasileira, professora e escritora.

\section{Tecendo A EscrevivênCIA de Conceição Evaristo}

"O olho do sol batia sobre as roupas estendidas no varal e mamãe sorria feliz. Gotículas de água aspergindo minha vida-menina balançavam ao vento. Pequenas lágrimas dos lençóis. Pedrinhas azuis, pedaços de anil, fiapos de nuvens solitárias caídas do céu eram encontradas ao redor das bacias e tinas das lavagens de roupas. Tudo me causava uma comoção

maior. A poesia me visitava e eu nem sabia..."

(EVARISTO, 2017b)

Nascida em 1946, em uma favela na cidade de Belo Horizonte, capital de Minas Gerais, Maria da Conceição Evaristo, filha de mãe lavadeira e herdeira de uma tradição de subalternidade e trabalhos femininos domésticos, precisou mudar-se para a cidade do Rio de Janeiro, em 1970, para poder ingressar no magistério público. Evaristo justifica sua mudança de cidade pelo fato de já ter reservado para si, em Belo Horizonte, destino semelhante ao das mulheres de sua família: o trabalho doméstico "Entrar para a carreira de magistério, naquela época, dependia de ser indicado por alguém e as nossas relações com as famílias importantes de Belo Horizonte estavam marcadas pela 
nossa condição de subalternidade" (EVARISTO, 2009). A passagem a seguir, que reproduz a própria voz da escritora, evidencia o contato de Evaristo com a tradição subalterna de sua família

Mãe lavadeira, tia lavadeira e ainda eficientes em todos os ramos dos serviços aprendi a arte de cuidar do corpo do outro. Aos oito anos surgiu meu primeiro emprego doméstico e ao longo do tempo, outros foram acontecendo. Minha passagem pelas casas das patroas foi alternada por outras atividades, como levar crianças vizinhas para escola, já que eu levava os meus irmãos. O mesmo acontecia com os deveres de casa. Ao assistir os meninos de minha casa, eu estendia essa assistência às crianças da favela, o que me rendia também uns trocadinhos. Além disso, participava com minha mãe e tia, da lavagem, do apanhar e do entregar trouxas de roupas nas casas das patroas. Troquei também horas de tarefas domésticas nas casas de professores, por aulas particulares, por maior atenção na escola e principalmente pela possibilidade de ganhar livros, sempre didáticos, para mim, para minhas irmãs e irmãos. (EVARISTO, 2009)

Já no Rio de Janeiro, Conceição Evaristo ingressa em 1976 no curso de Letras, na Universidade Federal do Rio de Janeiro. Interrompe-o em 1980, por conta do nascimento de sua filha Ainá e termina-o em 1989. Torna-se metre em Literatura Brasileira em 1996 pela Pontifícia Universidade Católica do Rio de Janeiro, e doutora em Literatura Comparada pela Universidade Federal Fluminense em 2011. Os temas que perpassam sua produção acadêmica são todos voltados à questão de literatura negra ${ }^{9}$. Evaristo, além de escrever literatura, reflete sobre o espaço da produção negra na literatura brasileira (MACHADO, 2014).

Embora tenha escrito desde muito jovem, sua primeira publicação se dá em 1990 quando passa a publicar seus contos e poemas na série Cadernos Negros, editados pelo grupo paulista Quilombhoje. Em 2003, arcando com os custos da publicação, a escritora publica o romance Ponciá Vicêncio, pela Editora Mazza; em 2006 publica, também pela Mazza, seu segundo romance Becos da Memória - embora esse seja seu primeiro romance escrito, veio a público somente anos depois de finalizado ${ }^{10}$. Além desses romances, Evaristo publica em 2008 uma coletânea com os poemas que veio escrevendo ao longo de sua trajetória Poemas da recordação e outros movimentos, pela editora Nadyala. Pela mesma editora, em 2011 publica o volume de contos Insubmissas lágrimas de mulheres; em 2014 publica pela editora Pallas Olhos d'água (contos) e em 2017, Histórias de leves enganos e parecenças (contos e novela), pela editora Malê. Nos últimos anos vêm crescendo o inte-

\footnotetext{
${ }^{9}$ Sua dissertação de mestrado, intitulada Literatura negra: uma poética de nossa afro-brasilidade (1996) traz uma reflexão crítica sobre a produção literária dos escritores e escritoras negros e negras brasileiros e brasileiras; sua tese de doutorado, chamada Poemas malungos: cânticos irmãos (2011) compara textos literários de literatura africana de língua portuguesa com textos da literatura afro-brasileira (MACHADO, 2014).

${ }^{10}$ No prefácio da $3^{a}$ edição do romance, Evaristo afirma “esta narrativa nasceu em 1987/88, sendo, pois, anterior à escrita dos contos e do romance Ponciá Vicêncio. Foi meu primeiro experimento em construir um texto ficcional con(fundindo) escrita e vida, ou, melhor dizendo, escrita e vivência. Talvez na escrita de Becos, mesmo que de modo quase que inconsciente, eu já buscava construir uma forma de escrevivência” (EVARISTO, 2017c, p. 9). Essa passagem evidencia uma escrita calcada, desde o início, em uma fusão de memória e ficção.
} 
resse por sua obra, que passou a ser traduzida para o francês (L 'histoire de Poncia, Anacaona, 2015; Banzo, mémoires de la favela, Anacaona, 2016; Insoumises, Anacaona, 2017) e para o inglês (Ponciá Vicêncio, Host Publications, 2007).

A análise da escrita de Evaristo evidencia o atravessamento de sua condição de mulher negra nascida em uma favela. Da dificuldade enfrentada pela escritora e por sua família na infância, Evaristo lança um olhar para a condição do negro na sociedade brasileira, marcada pela escravidão, exclusão, preconceito e exploração por meio do trabalho subalterno e mal pago. Nesse contexto, Evaristo cunha o termo escrevivência para nomear uma escrita que se mescla com a sua vivência, com o relato das suas memórias e das de seu povo. Transcrevemos, na sequência, um excerto de uma entrevista em que a escritora discorre a esse respeito

Quando eu usei o termo é... escrevivência [...] se é um conceito, ele tem como imagem todo um processo histórico que as africanas e suas descendentes escravizadas no Brasil passaram. Na verdade, ele nasce do seguinte: quando eu estou escrevendo e quando outras mulheres negras estão escrevendo, é... me vem muito na memória a função que as mulheres africanas dentro das casas-grandes escravizadas, a função que essas mulheres tinham de contar história para adormecer os da casa-grande, né... a prole era adormecida com as mães pretas contando histórias. Então eram histórias para adormecer. E quando eu digo que os nossos textos, é..., ele tenta borrar essa imagem, nós não escrevemos pra adormecer os da casa-grande, pelo contrário, pra acordá-los dos seus sonos injustos. E essa escrevivência, ela vai partir, ela toma como mote de criação justamente a vivência. Ou a vivência do ponto de vista pessoal mesmo, ou a vivência do ponto de vista coletivo. (EVARISTO, 2017a, grifos nossos)

Buscaremos, nos próximos itens, analisar, considerando as ideias de Pêcheux, aspectos dessa escrevivência do ponto de vista pessoal e coletivo em três poemas de Conceição Evaristo, a fim de compreender de que forma esse fazer literário acorda os da casa-grande de seus sonos injustos, perturbando e reorganizando o tecido da memória brasileira.

\section{A Poeta Interpelada Ao Escrever}

Iniciamos nossa análise com o poema Ao escrever... por se tratar de um texto metalinguístico, isto é, um texto em que Evaristo escreve sobre o próprio fazer poético. Transcrevemos o poema na sequência.

Ao escrever...

Ao escrever a fome com as palmas das mãos vazias quando o buraco-estômago expele famélicos desejos 


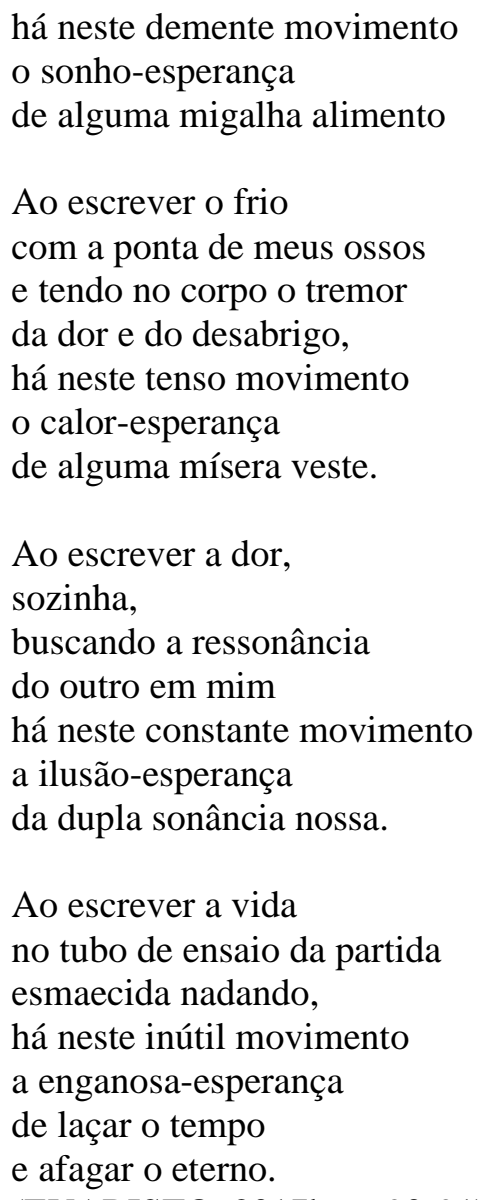

(EVARISTO, 2017b, p. 90-91)

A análise evidencia o percurso da poeta: ela escreve sobre a fome, o frio, a dor e a vida. A fome é escrita na esperança de ser saciada, de receber alguma migalha alimento; o frio, da mesma maneira, é motivo de escrita para o recebimento de uma mísera veste. Ao escrever a fome e o frio, a poeta sente em seu corpo os efeitos dessa condição: para a primeira, tem as mãos vazias e o estomago em estado de buraco; para a segunda, sente o tremor na ponta de seus ossos. Fome e frio surgem como primeiros motes de seu fazer poético e revelam a formação discursiva do abandono, da miséria, da vida dos sujeitos deixados à margem da sociedade e que precisam da misericórdia alheia para obter sustento para saciar a fome, e roupa para suportar o frio. Essa formação discursiva nos remete às pessoas em situação de rua, que perambulam pelos grandes centros, nos sinais de trânsitos, debaixo de marquises, em favelas, em abrigos, em suma, em locais apartados da sociedade, reproduzindo seus dizeres de pedintes, de quem sobrevive pela caridade e pela esmola.

O terceiro mote da poeta é a dor, que escreve sozinha para buscar a ressonância do outro. É possível compreender tal ressonância como o eco do outro em sua escrita para que, por meio de seu ato de escrever, poeta e outro ecoem como dupla sonância. Nesse momento, Evaristo evidencia que sua escrita é marcada pela alteridade, pois traz uma voz além da sua, a voz do outro, esse outro marginalizado e sem voz que se soma à sua fala e pode, então, ser ouvido (mesmo que tal gesto 
represente uma ilusão-esperança). O último mote, a vida, surge como vida esmaecida, fiapo de vida que se esvai nadando, aparece de partida e representa uma esperança (agora uma esperança enganosa) da poeta em segurar o tempo e afagar o eterno. Segurar o tempo jamais no sentido de não mudar essa condição, mas parar essa condição de dor e abandono e afagar, acarinhar essa vida em condição desumana à que empresta a voz, fazendo uma denúncia desse modo de existir.

Também é relevante notar que a escrita é representada como movimento, ora demente, ora tenso, ora constante, ora inútil. Percebemos que tal movimento perpassa por interdiscursos presentes nas diferentes formações discursivas. Devemos lembrar que uma formação discursiva “não é um espaço estrutural fechado, pois é constitutivamente 'invadida' por elementos que vêm de outro lugar (de outras formações discursivas) que se repetem nela, fornecendo-lhe suas evidências discursivas fundamentais" (PÊCHEUX, 1993, p. 314). Dessa forma, o movimento de escrever a poesia acompanha discursos transversos que se fundem em diferentes formações e se propagam na materialidade do poema: fome, frio e dor.

Conceição Evaristo, ao escrever, é interpelada a assumir uma posição-sujeito que denuncia a situação vivida pela população negra brasileira em condição de miséria. Denuncia não somente porque a observa e a descreve, mas porque, sobretudo, soma-se à condição dessa população e lhe empresta a voz em diferentes movimentos, com a esperança que esse gesto ecoe e seja sentido pelos seus leitores, certamente pessoas que vivem em condição diferente. Além disso, há nessa escrita um acontecimento discursivo: ao enunciar seus versos no presente, a poeta recupera uma memória social e suas diferentes formações discursivas localizadas na dimensão horizontal dos discursos e as sintagmatiza em posição horizontal, disparando novos efeitos de sentido e de paráfrase e reorganizando o tecido da memória.

\section{A Memória Social de Todas As Manhã}

Passamos agora à análise de Todas as manhãs, transcrito na sequência. Trata-se de um poema que faz um movimento entre presente, passado e futuro, movimento esse sustentado pela memória social.

Todas as manhãs

Todas as manhãs acoito sonhos e acalento entre a unha e a carne uma agudíssima dor. 
Todas as manhãs tenho os punhos sangrando e dormentes

tal é a minha lida cavando, cavando torrões de terra, até lá, onde os homens enterram

a esperança roubada de outros homens.

Todas as manhãs junto ao nascente dia ouço a minha voz-banzo, âncora dos navios de nossa memória.

E acredito, acredito sim que os nossos sonhos protegidos pelos lençóis da noite ao se abrirem um a um no varal de um novo tempo escorrem as nossas lágrimas fertilizando toda a terra onde negras sementes resistem reamanhecendo esperanças em nós.

(EVARISTO, 2017b, p. 13)

O poema é composto por três estrofes iniciadas com todas as manhãs, que dão ao texto um efeito de repetibilidade. $\mathrm{O}$ uso da anáfora produz um efeito que inscreve o discurso na ordem daquilo que é naturalizado, o discurso encontra-se com a memória localizada em sua dimensão vertical e passa a ser horizontalizado, isto é, formulado e dito, de modo que "os discursos se repetem, ou melhor, há repetições que fazem discursos" (COURTINE; MARANDIN, 1981, p. 28, apud INDURSKI, 2003, p. 102). É justamente pela repetição que a escrita de Evaristo surge como acontecimento discursivo que rompe com o ciclo de repetibilidade, mobilizando a memória e entrecruzando-a com os enunciados do presente, tensionando-a e projetando a construção de novos efeitos de sentido. Vejamos como se dá esse movimento.

A poeta protege os sonhos e acalenta a dor na primeira estrofe; na segunda, recupera a memória da escravidão da população negra no Brasil; na terceira, enuncia a voz do povo escravizado, sem voz, e projeta a proteção de sonhos que irão fertilizar a terra onde esse povo existe e resiste, possibilitando um resgate da esperança. Novamente vemos que a poeta sente em seu corpo os efeitos da dor produzida pela condição causada pela escravidão criminosa dos negros. Diz isso explicitamente na primeira estrofe (acalento entre a unha e a carne uma agudíssima dor) e, na segunda, mostra as consequências do trabalho escravo (tenho os punhos sangrando e dormentes). Também na segunda estrofe, há uma referência imediata ao trabalho da população negra escravizada e responsável pela construção do nosso país, como o trabalho nas minas e na agropecuária, no período da ascensão da mineração em Minas Gerais (tal é a minha lida cavando, cavando torrões de terra). Já no tempo presente, na terceira estrofe, a poeta recupera sua voz-banzo, 
a voz dos escravizados onde se ancoram os navios da memória, e instaura o acontecimento que permite perturbar essa rede de formulações discursivas: projeta sonhos protegidos pelos lençóis da noite.

Esse projetar de sonhos adormecidos e silenciados evidencia a resistência do eu-lírico. Os sonhos na última estrofe do poema são projetados como possibilidade concreta: a um novo tempo que se abre, os sonhos crescem como sementes escondidas na terra. Por meio da memória, esses sonhos são protegidos e resgatados. A memória atua nesse poema como resistência, como âncora de sonhos que não devem permanecer embaixo da terra sem florescer, mas devem fertilizar a esperança de novos tempos, um tempo em que não há mais opressão nem silenciamento.

Nesse sentido, é possível inferir que Evaristo assume, ao mesmo tempo, o lugar de guardiã e guerreira da memória e seu acontecimento, isto é, a enunciação dessa memória no presente, possibilita que se evite a repetibilidade inscrita no passado.

\section{A Reconstrução do Tecido da Memória Pelas Vozes-Mulheres}

Por fim, com Vozes-Mulheres pretendemos evidenciar como a escrita de Evaristo reconstrói o tecido da memória brasileira, por meio da articulação de diferentes vozes que se atualizam e reconstituem a memória. Vejamos o poema.

Vozes-Mulheres

A voz de minha bisavó ecoou criança nos porões do navio. ecoou lamentos de uma infância perdida.

A voz de minha avó coou obediência aos brancos-donos de tudo.

A voz de minha mãe ecoou baixinho revolta no fundo das cozinhas alheias debaixo das trouxas roupagens sujas dos brancos pelo caminho empoeirado rumo à favela. 


\author{
A minha voz ainda \\ ecoa versos perplexos \\ com rimas de sangue \\ e \\ fome.
}

\author{
A voz de minha filha \\ recolhe em si \\ a fala e o ato. \\ O ontem - o hoje - o agora. \\ $\mathrm{Na}$ voz de minha filha \\ se fará ouvir a ressonância \\ O eco da vida-liberdade.
}

(EVARISTO, 2017b, p. 24-25)

Esse poema narra, em seis estrofes, a trajetória das mulheres negras preservada na memória coletiva do povo brasileiro. Tal trajetória é recontada pela poeta e já é evidenciada no título Vozes-Mulheres, destacando tratar-se de vozes femininas, que ecoam pelo texto em movimento que vem do passado, passa pelo presente e se projeta no futuro. São, além disso, vozes que fazem parte da história de vida da poeta, pois são qualificadas com o pronome possessivo minha. Vejamos quais são essas vozes e que memória emerge de seus ecos.

A primeira estrofe apresenta a voz da bisavó da poeta, que ecoa dos navios, melhor dito, dos porões do navio. O eco dessa voz recupera a memória da diáspora do povo africano, do momento em que foram arrancados à força de suas terras e lançados em porões de navios para serem vendidos, vandalizados e comercializados como escravos. A voz da bisavó, desse local de cativeiro, ecoa lamentos de uma infância perdida. Temos, na sequência, o eco da voz da avó, que enuncia obediência, portanto silêncio e submissão, representando a escravidão do negro no Brasil - a voz ecoa essa obediência aos brancos-donos de tudo. A voz da mãe da poeta surge na terceira estrofe do fundo das cozinhas, debaixo de trouxas de roupas sujas e, embora ecoe baixinho revolta, já começa a ecoar enquanto ruma aos caminhos das moradas às margens. Por meio dessa voz, podemos resgatar a memória dos negros recém-libertos, mas que foram rejeitados dos centros urbanos e destinados à exclusão, à pobreza, à marginalização e aos becos e favelas. A voz da mãe também evidencia o 
trabalho doméstico subalterno e silenciado, pois ecoa do fundo das cozinhas alheias, ou seja, ainda não há um deslocamento do lugar social.

As duas vozes presentes nas três últimas estrofes agora ecoam no tempo presente, demarcando que estamos diante de um acontecimento discursivo. Primeiramente temos a própria voz da poeta que ainda ecoa essa memória, mas agora já pode denunciá-la - não é mais necessário que ecoe das cozinhas alheias, das favelas, dos porões do navio. Essa voz, porém, enuncia ainda dor e miséria, pois se mantém muito próxima das vozes anteriores, reverberando-as. A diferença é que agora estamos diante de um encontro entre uma memória e uma atualidade (PÊCHEUX, 2015b) que produz uma primeira ruptura e, por consequência, perturbação no eixo vertical da memória e de suas formações discursivas anteriores - a da diáspora, da escravidão e da "libertação".

O segundo acontecimento, que é definitivo para a desestabilização da memória, surge na voz da filha. É uma voz que recolhe todas as anteriores e agora se faz ato, torna-se cidadã, pois fazer-se ato significa agir e interferir, ao contrário das vozes anteriores que eram de servidão e obediência. Temos na voz da filha, marcas materiais do acontecimento discursivo: o ontem, o hoje, o

agora. É, pois, por meio da voz da filha que se fará ouvir a ressonância, o eco da vida-liberdade, isto é, uma vida que teria como relação de antonímia um nome composto como vida-prisão, vida aprisionada.

Por meio das vozes dessas mulheres negras, de suas mulheres negras, podemos perceber que Evaristo, conforme dissemos, com sua escrita que se situa como acontecimento discursivo, perturba a estabilização da memória, remodelando seu tecido e permitindo que se entrecruzem por suas diversas redes novos efeitos de sentido e de paráfrase. Compreender esse continuum contribui para que possamos entender as inúmeras tramas que constituem a tessitura histórico-cultural da memória da população negra brasileira.

\section{TeCendo Algumas Considerações}

Ao mobilizarmos as ideias de Pêcheux para analisar os poemas de Conceição Evaristo, jogamos luzes sobre o tecido da memória social e sua instabilidade, pois a análise revela a mobilidade e a possibilidade de remodelagem e reajuste desse tecido, que pode ser perfurado e deslocado a cada acontecimento. Esse deslocamento produz efeitos de sentido e gera novos dizeres, com novos efeitos de paráfrase, que percorrem diferentes formações discursivas e interpelam novas posições-sujeito.

Nesse sentido, a própria Evaristo, ao falar de sua escrita, argumenta que "Entre o acontecimento e a narração do fato, há um espaço em profundidade, é ali que explode a invenção" 
(EVARISTO, 2017c, p. 11). Acreditamos que esse espaço entre o acontecido e o narrado, no qual a poeta cria seus motes, é o espaço de sua escrevivência, isto é, da escrita que se funde à sua vivência e à dos seus. Procuramos demonstrar, pois, de que maneira os versos de Conceição Evaristo, tomados em sua materialidade discursiva, atuam como o acontecimento que perfura a memória discursiva, alterando sua regularidade e provocando a remodelagem de seu tecido.

\section{REFERÊNCIAS BIBLIOGRÁFICAS}

ACHARD, Pierre. Memória e produção discursiva do sentido. In: ACHARD, Pierre. Papel da memória. Campinas, SP: Pontes Editores, 1999, p. 11-19.

ALTHUSSER, Louis. Ideologia e aparelhos ideológicos de Estado. Lisboa: Editorial Presença/Martins Fontes, 1980.

COURTINE, Jean-Jacques. O tecido da memória: algumas perspectivas de trabalho histórico nas ciências da linguagem. Polifonia, Cuiabá, v. 12, n. 2, p. 1-13, 2006.

EVARISTO, Conceição. Escritora Conceição Evaristo é convidada do Estação Plural: depoimento [jun. 2017]. Entrevistadores: Ellen Oléria, Fernando Oliveira e Mel Gonçalves. TVBRASIL, 2017a. YouTube. Disponível em: https://www.youtube.com/watch?v=Xn2gj1hGsoo. Acesso em 15 jul. 2018.

EVARISTO, Conceição. Poemas da recordação e outros movimentos. Rio de Janeiro: Malê, $2017 \mathrm{~b}$.

EVARISTO, Conceição. Depoimento cedido durante o I Colóquio de Escritoras Mineiras, realizado em maio de 2009, na Faculdade de Letras da UFMG. Disponível em:

http://www.letras.ufmg.br/literafro/autoras/188-conceicao-evaristo. Acesso em: 15 jul. 2018.

EVARISTO, Conceição. Becos da memória. Rio de Janeiro: Pallas, 2017c.

FOUCAULT, Michel. As formações discursivas. In: FOUCAULT, Michel. A arqueologia do saber. Rio de Janeiro: Forense Universitário, 2008, p.35-55.

INDURSKI, Freda. Lula lá. Estrutura e acontecimento. Organon, Porto Alegre: UFRGS, v. 17, n. 35, p. 101-121, 2003.

MACHADO, Bárbara Araújo. Escre(vivência): a trajetória de Conceição Evaristo. Revista História Oral, v. 17, n.1, p. 243-265, 2014.

PÊCHEUX, Michel. A análise de discurso: três épocas (1983). In: GADET, F.; HAK, T. (org.) Por uma análise automática do discurso: uma introdução à obra de Michel Pêcheux. Campinas, SP: Editora da UNICAMP, 1993. p. 311-319.

PÊCHEUX, Michel. Discurso e ideologia (s). In: PÊCHEUX, Michel. Semântica e discurso: uma crítica à afirmação do óbvio. Campinas, SP: Editora da Unicamp, 2014. p. 129-168.

PÊCHEUX, Michel. Metáfora e interdiscurso. In: PÊCHEUX, Michel. Análise de discurso. Campinas, SP: Pontes Editores, 2015a, p. 151-161.

PÊCHEUX, Michel. O discurso: estrutura ou acontecimento. Campinas, SP: Pontes Editores, 2015b.

PÊCHEUX, Michel. O papel da memória. In: ACHARD, Pierre et al. Papel da memória. Campinas, SP: Pontes Editores, 1999. p. 49-57. 